\title{
Consequence of indoor air pollution in rural area of Nepal: a simplified measurement approach
}

\author{
Chhabi Lal Ranabhat ${ }^{1,2}$, Chun-Bae Kim ${ }^{1,2}{ }^{\text {, Chang-Soo Kim }}{ }^{2}$, Nilambar Jha ${ }^{3}$, K. C. Deepak ${ }^{3}$ and \\ Fredric A. Connel ${ }^{4}$
}

${ }^{1}$ Department of Preventive Medicine, Wonju College of Medicine Yonsei University, Wonju, Gangwon, South Korea

${ }_{2}$ Institute for Poverty Alleviation and International Development, Yonsei University, Wonju, Gangwon, South Korea

${ }^{3}$ BP Koirala Institute of Health Science, School of Public Health and Community Medicine, Dharan, Nepal

${ }^{4}$ Department of Health Services, School of Public Health, University of Washington, Seattle, WA, USA

\section{Edited by:}

Mohiuddin Md. Taimur Khan, Washington State University, USA

Reviewed by:

Durg Vijai Singh, Institute of Life Sciences, India

Hui Hu, University of Florida, USA

*Correspondence:

Chun-Bae Kim, Yonsei University,

Wonju College of Medicine, 162

Ilsandong, 220-701 Gangwon

e-mail:kimcb@yonsei.ac.kr
People of developing countries especially from rural area are commonly exposed to high levels of household pollution for $3-7 \mathrm{~h}$ daily using biomass in their kitchen. Such biomass produces harmful smoke and makes indoor air pollution (IAP). Community-based cross-sectional study was performed to identify effects of IAP by simplified measurement approach in Sunsari District of Nepal. Representative samples of 157 housewives from household, involving more than 5 years in kitchen were included by cluster sampling. Data were analyzed by SPSS and logistic regression was applied for the statistical test. Most $(87.3 \%)$ housewives used biomass as a cooking fuel. Tearing of eyes, difficulty in breathing, and productive cough were the main reported health problems and traditional mud stoves and use of unrefined biomass were statistically significant $(p<0.05)$ and more risk $(A O R>2)$ with health problems related to IAP. The treatment cost and episodes of acute respiratory infection was $>2$ folders higher in severe IAP than mild IAP. Simplified measurement approach could be helpful to measure IAP in rural area. Some effective intervention is suggested to reduce the severe level of IAP considering women and children.

Keywords: indoor air pollution, biomass, acute respiratory infection, health problems, cooking fuel

\section{INTRODUCTION}

Indoor air pollution (IAP) can be traced to prehistoric times when humans first moved to temperate climates and it became necessary to construct shelters and use fire inside them for cooking, warmth, and light. Fire led to exposure to high levels of pollution, as evidenced by the soot found in prehistoric caves (1). Approximately half of the world's population and up to $90 \%$ of rural households in the developing countries still rely on unprocessed biomass fuels in the form of wood, dung, and crop residues (2). People in developing countries are commonly exposed to high levels of pollution for 3-7 h daily over many years (3). During winter in cold and mountainous areas, exposure may occur over a substantial portion of each 24-h period (4). Because of their customary involvement in cooking, especially women's exposure is much higher than men's (5). Young children are often carried on their mothers' backs while cooking is in progress and therefore spend many hours breathing smoke (1).

Many of the substances in biomass smoke can damage human health. The most important (substances) are particles, carbon monoxide, nitrous oxides, sulfur oxides (principally from coal), formaldehyde, and polycyclic organic matter, including

Abbreviations: ALRI, acute lower respiratory infection; ARI, acute respiratory infection; $\mathrm{CI}$, confidence interval; $\mathrm{COPD}$, chronic obstructive pulmonary disease; $\mathrm{CD}$, cluster of difference; DAG, disadvantage group; FGD, focus group discussion; IPAID, Institute for Poverty Alleviation and International Development; WHO, World Health Organization. carcinogens such as benzopyrene (6). Particles with diameters below $10 \mu\left(\mathrm{PM}_{10}\right)$, and particularly those $<2.5 \mu$ in diameter $\left(\mathrm{PM}_{2.5}\right)$, can penetrate deeply into the lungs and appear to have the greatest potential for damaging health (7). The pollutants produced by unprocessed fuel are carbon monoxide, sulfur oxide, particles, and volatile organic, which are responsible to produce different disease and illness in human beings (8). The pollutants from biomass increase the risk of acute respiratory infections (ARIs) in childhood, chronic obstructive pulmonary disease (COPD) and lung cancer in adult $(9,10)$. It is the most important cause of death for children under five in developing countries. Evidence also exists of associations with low birth weight (LBW), increased infant and perinatal mortality, pulmonary tuberculosis, nasopharyngeal and laryngeal cancer, cataract, and, specifically in respect of the exposure of coal, with lung cancer to the non-smoker too $(1,11)$. Biomass users illustrated high suppression in the total number of T-helper (CD4+) cells and $\mathrm{B}(\mathrm{CD} 19+)$ cells, while appreciable rise was documented in the number of CD8+ T-cytotoxic cells and CD16+CD56+ natural killer (NK) cells and consistent finding among biomass users was rise in regulatory $\mathrm{T}$ (Treg) cells (12). It proved that IAP is not only arising the health problems but also responsible to worsen the other disease and illness by reducing the immunity.

Nepal is the country of village where $>80 \%$ live in villages and $75 \%$ population are using the unprocessed biomass like firewood, animal dung, and some paper residue leaves of trees as a 
Table 1 | Average magnitude of pollutants within household

\begin{tabular}{llcc}
\hline S No & Category & $\begin{array}{c}\mathbf{P M}_{\mathbf{2 . 5}-\mathbf{1 0}} \\
\mathbf{( m g ~ m}^{\mathbf{3}} \mathbf{)}\end{array}$ & $\mathbf{C O}$ (PPM) \\
\hline 1 & Smoking per episode within room & $14(20)$ & 65.5 \\
2 & Biomass & 263 & $62.6(21)$ \\
3 & Clean fuel & 133 & Few \\
4 & Non-ventilation & 0.45 & 11 \\
5 & Ventilation & 0.10 & $1.6-4.4$ \\
6 & Pollutant coverage (kitchen) & 652 & $5.1-5.8$ \\
7 & Pollutant coverage (outside the kitchen) & 297 & Few \\
6 & Open fire space/traditional mud stove & 0.45 & 4.4 \\
7 & Improve cooking stove & 0.10 & 0.7 \\
\hline
\end{tabular}

Table 2 | Degree of air pollution from Table 1.

\begin{tabular}{lll}
\hline Mild/no IAP & Average IAP & Severe IAP \\
\hline $\begin{array}{l}\text { Separate kitchen } \\
\text { At least 1 window } \\
\text { or ventilation }\end{array}$ & Separate kitchen & No window/ventilation \\
$\begin{array}{l}\text { Improve cooking } \\
\text { stove }\end{array}$ & Improve window/ventilation \\
$\begin{array}{l}\text { No Smoke within } \\
\text { family }\end{array}$ & No smoke within family & Smoking person in family \\
$\begin{array}{l}\text { Alternative using } \\
\text { biomass }\end{array}$ & Always using biomass & Always using biomass \\
\hline
\end{tabular}

kitchen fuel (13). The housing structure is very vulnerable for IAP because $70 \%$ households have wooden and mud bonded house with poor ventilation (14). Here, the majority of populations live in countryside and they used unprocessed biomass as a cooking fuel. As a result, the situation of ARI and skin diseases has been first and second in morbidity rank each year. In addition, the COPDs, eye problems, and other cough related diseases are frequently recurrent disease. So, there could be some association with the housing condition and IAP (15).

To study the magnitude of harmful gas like carbon dioxide, carbon monoxide, nitrogen oxide, benzene butadiene, formaldehyde, etc., there is necessary to measure the pollutants by some sophisticated equipment at the level of $>10$ p.m. Such approach can precise the level of IAP produced from different sources, but they are quite unpractical in a rural context for the household and the researchers. There is still lacking to measure the indoor air pollutants by simple methods and arising health problems due to the long exposure in rural areas and developing countries. The simplified IAP measurement questionnaire was prepared based on Warwick H. study (16) related to type of stoves, type of fuel, used in kitchen, smoking situation in family members, and some behavioral pattern of cooking member than any devices. The main objective of this research is to explore the health consequence related to IAP and its major effects as well as the relation of some factors in community level without sophisticated measurement of the pollutants and clinical diagnosis of the health problems.
Table 3 | Assessment of health status

\begin{tabular}{|c|c|c|}
\hline S No & Conditions & Response \\
\hline 1 & $\begin{array}{l}\text { Do you have health problems since you are } \\
\text { involving long time in your kitchen? }\end{array}$ & $\begin{array}{l}\text { Yes } \\
\text { No }\end{array}$ \\
\hline 2 & How many times did you suffer since 1 year? & \\
\hline 3 & $\begin{array}{l}\text { If yes, what kinds of health problems do you } \\
\text { have? (multiple response) }\end{array}$ & $\begin{array}{l}\text { Difficulty in } \\
\text { breathing } \\
\text { Dry cough } \\
\text { Productive cough } \\
\text { Tearing of eyes } \\
\text { Itching of skin } \\
\text { Headache } \\
\text { Vertigo } \\
\text { Others......... }\end{array}$ \\
\hline 4 & Are those problems recurrent? & $\begin{array}{l}\text { Yes } \\
\text { No }\end{array}$ \\
\hline 5 & $\begin{array}{l}\text { Do your kids }(<5 \text { years suffering from ARI } \\
\text { since } 1 \text { year? }\end{array}$ & $\begin{array}{l}\text { Yes } \\
\text { No }\end{array}$ \\
\hline 6 & $\begin{array}{l}\text { How many times did he/she attack since last } \\
\text { year? }\end{array}$ & $\ldots \ldots \ldots$ \\
\hline 7 & Where did you treat? & $\begin{array}{l}\text { Home remedy } \\
\text { Hospitals and } \\
\text { health centers }\end{array}$ \\
\hline 8 & $\begin{array}{l}\text { How much did you pay (in Nrs) for the } \\
\text { treatment in last year for ARI to your children? }\end{array}$ & $\ldots$ \\
\hline
\end{tabular}

\section{METHODOLOGY}

\section{STUDY POPULATION AND SAMPLING}

The study was a cross-sectional study conducted in Khanar village development committee (VDC); a grass root level political division in Sunsari District of Nepal in 2013. The VDC was selected purposively. Cluster sampling method was used to involve all kinds of geographical area. The sample size was calculated on the basis of proportion of using biomass (72.3\%) (14) as 157 households and the housewives were included in the study who are involving in their kitchen more than 5 years. The sample size were calculated on Cochran equation (17) where the sample size would be: $Z$ denotes the abscissa of the normal curve that cuts off an area $\alpha$ at the both tails $(1-\alpha$ equals the desired confidence level, e.g., $95 \%), e$ is the desired level of precision (0.07), $p$ is the estimated proportion (0.72) of an attribute that is present in the population, and $q$ is $1-p$ which is 0.28 .

\section{DATA COLLECTION AND INSTRUMENTS}

Semi-structure interview, observation, and focus group discussion methods were used to collect information. The questionnaire, observation checklist, and interview guideline were the tool and translated in Nepali language. Questionnaires were pre-tested in Tarahara VDC. After the pre-test in 20 households, we modified the observation checklist about the kitchen situation. The field researchers were selected based on their previous experiences, 
Table 4 | Descriptive findings from study $(N=157)$

\begin{tabular}{|c|c|c|c|c|c|c|}
\hline \multirow[t]{2}{*}{ Characteristics } & \multirow[t]{2}{*}{ Variables } & \multirow[t]{2}{*}{ Category } & \multicolumn{3}{|c|}{ Grading IAP No. (\%) } & \multirow[t]{2}{*}{$p$ Value } \\
\hline & & & No/mild IAP (\%) & Average IAP (\%) & Severe IAP (\%) & \\
\hline \multirow[t]{16}{*}{ Demographic variables } & Education & Illiterate & $3(23.1)$ & $8(61.5)$ & $2(15.4)$ & $<0.001$ \\
\hline & & Primary & $7(14.6)$ & $33(68.8)$ & $8(16.7)$ & \\
\hline & & Secondary & $7(15.2)$ & $23(50)$ & $16(34.8)$ & \\
\hline & & Higher education & $2(4.0)$ & $18(36.0)$ & $30(60.0)$ & \\
\hline & Geographical location & Rural & $6(4.8)$ & $70(55.6)$ & $50(39.7)$ & $<0.001$ \\
\hline & & Semi urban & $13(41.9)$ & $12(38.7)$ & $6(19.4)$ & \\
\hline & Caste & DAG & $1(7.1)$ & $8(57.1)$ & $5(35.7)$ & 0.82 \\
\hline & & Non-DAG & $18(12.6)$ & $74(51.7)$ & $51(35.7)$ & \\
\hline & Per capita income per month & Up to $100 \$$ & $13(10.1)$ & $64(49.6)$ & $52(40.3)$ & 0.05 \\
\hline & & $100-200 \$$ & $5(19.2)$ & $17(65.4)$ & $4(15.4)$ & \\
\hline & & $>200 \$$ & $1(50.0)$ & $1(50.0)$ & $0(0.0)$ & \\
\hline & Having own cultivating land & No & $11(11.3)$ & $58(59.8)$ & $28(28.9)$ & 0.04 \\
\hline & & Yes & $8(13.3)$ & $24(40.0)$ & $28(46.7)$ & \\
\hline & Housing category & Dwelling and risk & $12(40)$ & $16(53.3)$ & $2(6.7)$ & $<0.001$ \\
\hline & & Semi dwelling & $2(14.3)$ & $8(57.1)$ & $4(28.6)$ & \\
\hline & & Concrete/safe & $5(4.4)$ & $58(51.3)$ & $50(44.2)$ & \\
\hline \multirow[t]{13}{*}{ Factors related to IAP } & Smoking behavior & No & $18(19.4)$ & $73(78.5)$ & $2(2.2)$ & $<0.001$ \\
\hline & & Yes & $1(1.6)$ & $9(14.1)$ & $54(84.4)$ & \\
\hline & Separate kitchen & No & $4(11.4)$ & $15(42.9)$ & $16(45.7)$ & 0.35 \\
\hline & & Yes & $15(12.3)$ & $67(54.9)$ & $40(32.8)$ & \\
\hline & Cooking fuel & Biomass & $9(6.9)$ & 68 (51.9) & $54(41.2)$ & $<0.001$ \\
\hline & & No biomass & $10(38.5)$ & $14(53.8)$ & $2(7.7)$ & \\
\hline & Ventilation in kitchen & No & $5(3.8)$ & $71(54.6)$ & $54(41.5)$ & $<0.001$ \\
\hline & & Yes & $14(51.9)$ & $11(40.7)$ & $2(7.4)$ & \\
\hline & Stove used during cooking & Traditional mud & $2(1.8)$ & $58(52.3)$ & 51 (45.9) & $<0.001$ \\
\hline & & Improved cooking & $4(20.0)$ & $14(70.0)$ & $2(10.0)$ & \\
\hline & & Electric/gas & $13(50.0)$ & $10(38.5)$ & $3(11.5)$ & \\
\hline & Health problems & Yes & $1(0.9)$ & $75(54.7)$ & $62(44.4)$ & $<0.001$ \\
\hline & & No & $9(45.0)$ & $9(45.0)$ & $1(10.0)$ & \\
\hline
\end{tabular}

familiarity with study areas, local language, and culture and they were provided intensive training to get the adequate information and minimizing the errors.

\section{HEALTH PROBLEMS AND GRADING OF IAP}

Health problems arises due to IAP was asked to the respondents and they were taken as layman reporting as their symptoms rather than and lab/clinical diagnosis. The degree of IAP was plotted based on the Warwick article (16) and focus group discussion in that community. Likewise, it is very difficult to measure the pollutants without any equipment in rural areas. Based on the study by Chowdhury et al. (18) and Dasugupta et al. in Bangladesh (19), the severity of IAP has been measured in three category measuring carbon monoxide $(\mathrm{CO})$ and particulate matter $_{2.5-10}$ (Table 1).

From the above table, the magnitude of IAP was categorized into no/mild, average, and severe (Table 2). It is the simplified measurement based on above articles where the application of equipment to measure is impossible.
Furthermore, the category of the IAP was merged into two categories such as mild/no IAP to IAP (No) and average and severe IAP to IAP (Yes) due small or number of cell value during classification.

\section{ASSESSMENT OF HEALTH STATUS}

The health problems were asked to the respondents as like Table 3.

\section{ETHICAL CONSENTS}

Verbal consent was taken from each participant who involved in the study and also the written permission was taken from authority of BP Koirala Institute of Health Science Dharan Nepal.

\section{DATA ENTRY AND ANALYSIS}

Data were entered into Microsoft Excel and exported to SPSS 20.0. Logistic regression and odds ratio were applied to show the association in different variables. Some variables were merged who had small value during the statistical analysis. Education category, type of houses, and stove used during cooking had merged into 
Table 5 | Comparison of risk by odds ratio associated health problems on logistic regression.

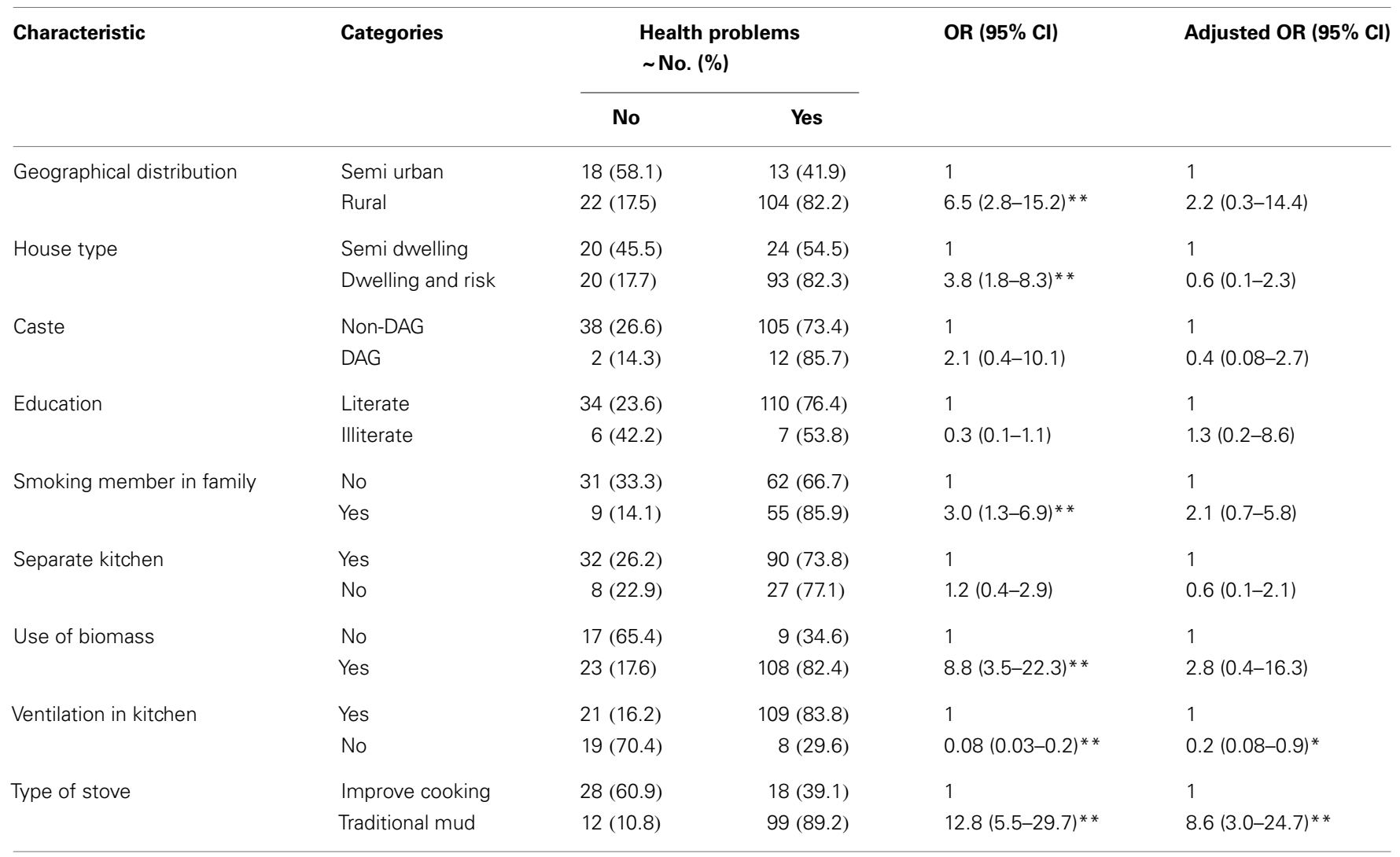

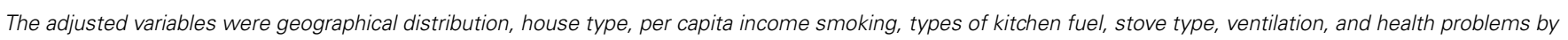
binary logistic regression. 1 is reference value.

${ }^{*} p<0.05,{ }^{*} p<0.001$.

two categories from three categories during multivariate analysis. The problems associated with IAP were found by verbal reporting during research. Data quality was maintained by pre-test of questionnaire, training of the field researchers, data verification, and cleansing in both excel and SPSS formats.

\section{RESULTS}

The study area was rural area of Sunsari District in south part. Most $(81.5 \%)$ household were under the poverty level $(<1 \$$ income/day). Except the caste (demographical variable) and separate kitchen (IAP factor), all variables were statistically significant (Table 4).

Bivariate and multivariate analysis was performed to show the association between some variables with the health problems. Table 5 shows the odds ratio before and after adjustment where traditional mud stove $(8.6 ; 3.0-24.7)$ and use of biomass (2.8; $0.4-16.3$ ) in $95 \% \mathrm{CI}$ were more risk than other variables.

In Table 6, there are indirect effects of the IAP. The treatment cost per household is three folder ( $301 \$$ vs. $893 \$$ ) higher in no/mild IAP than severe IAP. Similarly, average episode of the illness of child per year is almost double and average episode of illness adult is not high in severe IAP. Figure 1 shows the category of illness and it reveals $55.4 \%$ had tearing of eyes where as $6 \%$ reported vertigo since last year 2013.
Table 6 | Multiple effects associated with IAP.

\begin{tabular}{lllll}
\hline $\begin{array}{l}\text { Level of } \\
\text { indoor air } \\
\text { pollution }\end{array}$ & $\begin{array}{l}\text { Treatment } \\
\text { expenditure } \\
\text { in Rs/year/ } \\
\text { child }\end{array}$ & $\begin{array}{l}\text { Average } \\
\text { killing hour } \\
\text { in kitchen/ } \\
\text { day }\end{array}$ & $\begin{array}{l}\text { Average } \\
\text { episode of } \\
\text { illness of } \\
\text { adult/year }\end{array}$ & $\begin{array}{l}\text { Average } \\
\text { episode of } \\
\text { illness of } \\
\text { child/year }\end{array}$ \\
\hline No/mild IAP & 301 & 3 & 2.1 & 4.3 \\
Average IAP & 465 & 3.5 & 2.6 & 4.6 \\
Severe IAP & 893 & 5.2 & 3.4 & 7.8 \\
\hline
\end{tabular}

\section{DISCUSSION}

This study was carried out to explore the multiple effects of IAP in rural Terai area of Nepal. Before this study, some studies were conducted in hill and mountain area. Our study was simply designed but represents the global rural area. In other words, it is the simplest approach to find out the different magnitude of IAP in rural setting. Even it is useful to reduce the burden of IAP intervention strategy in small scale from the community level like during the construction of home and pollution free kitchen. The general illness was assessed that represents the morbidity pattern in the community without clinical and laboratory investigation. It is the significant achievement of the study. Poverty related factors like per capita income, education, housing condition, etc., are consistently 


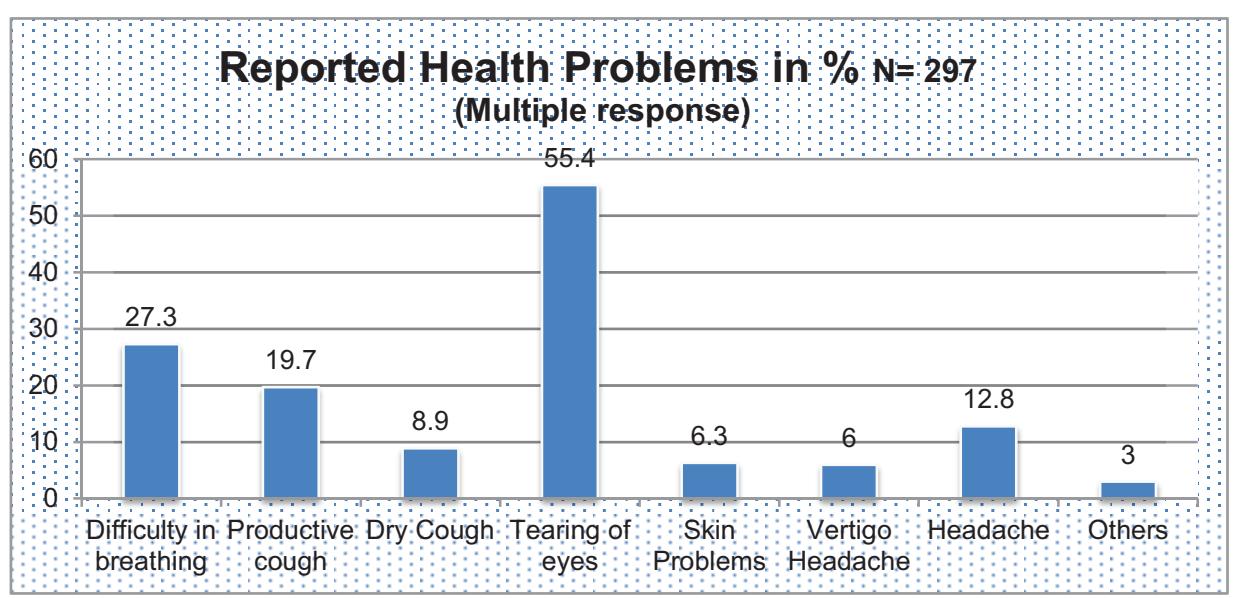

FIGURE 1 | Reported health problems due to indoor air pollution.

associated with IAP. Use of traditional mud stove and unrefined biomass is the major risk factors for health problems associated with IAP (Table 5). Since, respiratory illnesses are the major causes of morbidity and mortality globally and in Nepal also $(15,22)$.

The poor health outcomes of respondents and their children were associated IAP in our findings (Table 3; Figure 1). Similar results were found with other related studies. A qualitative study conducted in rural area of Lalitpur district of Nepal showed ARI was one of the most prevalent and common where there was hazy and severe indoor air smoke (23). The prevalence of respiratory illnesses and symptoms were considerably higher in those living in mud and brick houses compared with concrete houses and prevalence was also higher in those living on hills and in rural areas compared with flatland and urban areas (24). It is similar findings to our study that there is statistically significant housing type and IAP. ARI increased from 0.03 to 0.56 per child when exposure level increased from 0.09 hour category to $4+$ hours category, respectively, in poor communities (25). The prevalence of productive cough was $19.7 \%$ tearing of eyes is $55.4 \%$, difficulty on breathing is $27.3 \%$, asthma is $8.9 \%$, skin problems $6.3 \%$, vertigo $9.4 \%$, and headache $12.8 \%$ within cooking member of family who are involving $>5$ years in kitchen; $(25,26)$ similar results with our study.

In global context, there is strong evidence of an association with use of solid kitchen fuels and acute lower respiratory infections (ALRIs) in children aged $<5$ years in comparative health risk assessed by WHO in developing countries (27). The occurrence of associated diseases, like acute upper and lower respiratory infections, COPD, asthma, perinatal mortality, pulmonary tuberculosis, LBW, eye irritation and cataract, etc., in Uttar Pradesh, India to the women who were responsible in cooking through household biomass (28). Solid fuel smoke like coal, firewood, steam of trees, etc., possess the majority of the toxins found in tobacco smoke and has also been associated with a variety of diseases, such as COPD in women, ARI in children, and lung cancer in women in Mexico (29). Exposure to solid fuel smoke is consistently associated with COPD and chronic bronchitis in developing countries; especially Africa continents (30). Child ALRIs, LBW, stillbirth, preterm birth, stunting, and all-cause mortality in children and equally risk of COPD, tuberculosis, and even lungs cancer to their mothers were heavily associated with IAP in China (31). Continued exposure to smoke from traditional fuels has been shown to cause acute respiratory illnesses (ARI), COPDs, lung cancer, blindness, and TB in another study in China (32).

In Nepal's hill areas, women's total recorded work time was found to be between 150 and $180 \%$ of that of men, out of which $40 \%$ was spent on fuel collection alone (33). For the sites where deforestation was greatest, the time required to collect a standard load of fuel wood was $75 \%$ higher than it was where deforestation was low, which translated to a $45 \%$ increase in time spent for fuel wood collection (34). Additionally, spending hours for cooking in hazardous conditions in inefficient stoves result rise to eye infections and other respiratory problems. Similarly, women had to spend considerable amount of time in collecting kitchen fuel thereby reducing the time available for education and income generating activities (35). Our surplus findings show that the treatment cost is about three folder higher, average episodes being ill to children and adult, more than two times higher to spend time in kitchen in severe IAP than no/mild IAP. These associated findings show the indirect impact of IAP.

There are some limitations of this study, where one is the precision of IAP and another is confirmation of the disease or illness because there are no use of scientific equipment to measure the pollutant level and clinical diagnosis of disease/illness. Another, the severity of IAP was based on CO and PM though other pollutants were not taken into account. The level of precision was 0.07 due to errors in some samples. The condition of biomass (wet/dry), type of biomass, other human behaviors, etc., could not to include in the standard and need to verify by scientific equipment.

\section{CONCLUSION}

So in developing countries, most of the population is in rural area, they are suffering from IAP directly or indirectly especially women and children. There are some scientific standard of good housing (36), but they are not practical to improve in rural context. So, 
practical standards could be helpful to reduce the magnitude of IAP and reform the housing standard in those rural areas. This approach will not be gold standard to measure the indoor pollutants but screening process to measure the nature and magnitude of the pollution level by specific biomasses that are hazardous. Some effective interventions are suggested to reduce the severe level of IAP in community.

\section{ACKNOWLEDGMENTS}

This study was supported by WHO Nepal during field work. Also, the Institute for Poverty Alleviation and International Development (IPAID), Yonsei University, and the National Research Foundation by the Korean Government (NRF-2013S1A5B8A01055336) have supported during article writing and publication process of this study.

\section{REFERENCES}

1. Bruce N, Perez-Padilla R, Albalak R. Indoor air pollution in developing countries: a major environmental and public health challenge. Bull World Health Organ (2000) 78(9):1078-92. doi:10.1590/S0042-96862000000900004

2. Doll CH, Muller J-P, Elvidge CD. Night-time imagery as a tool for global mapping of socioeconomic parameters and greenhouse gas emissions. J Hum Environ (2000) 29(3):157-62. doi:10.1579/0044-7447-29.3.157

3. Engle PL, Hurtado E, Ruel M. Smoke exposure of women and young children in highland Guatemala: prediction and recall accuracy. Hum Organ (1997) 56(4):408-17.

4. Norboo T, Yahya M, Bruce N, Heady J, Ball K. Domestic pollution and respiratory illness in a Himalayan village. Int J Epidemiol (1991) 20(3):749-57. doi:10.1093/ije/20.3.749

5. Behera D, Dash S, Malik S. Blood carboxyhaemoglobin levels following acute exposure to smoke of biomass fuel. Indian J Med Res (1988) 88:522.

6. De Koning HW, Smith K, Last J. Biomass fuel combustion and health. Bull World Health Organ (1985) 63(1):11.

7. Pope CA III, Burnett RT, Thun MJ, Calle EE, Krewski D, Ito K, et al. Lung cancer, cardiopulmonary mortality, and long-term exposure to fine particulate air pollution. JAMA (2002) 287(9):1132-41. doi:10.1001/jama.287. 9.1132

8. Harrison R, Thornton C, Lawrence R, Mark D, Kinnersley R, Ayres J. Personal exposure monitoring of particulate matter, nitrogen dioxide, and carbon monoxide, including susceptible groups. Occup Environ Med (2002) 59(10):671-9. doi:10.1136/oem.59.10.671

9. Smith KR. Biofuels, Air Pollution, and Health: A Global Review. Plenum Press (1987).

10. Chen B, Hong C, Pandey MR, Smith KR. Indoor air pollution in developing countries. World Health Stat Q (1990) 43(3):127-38.

11. Mu L, Liu L, Niu R, Zhao B, Shi J, Li Y, et al. Indoor air pollution and risk of lung cancer among Chinese female non-smokers. Cancer Causes Control (2013) 24(3):439-50. doi:10.1007/s10552-012-0130-8

12. Dutta A, Bhattacharya P, Lahiri T, Ray MR. Immune cells and cardiovascular health in premenopausal women of rural India chronically exposed to biomass smoke during daily household cooking. Sci Total Environ (2012) 438:293-8. doi:10.1016/j.scitotenv.2012.08.065

13. Center Beureo of Statistics. District Level Detail Report. Kathmandu: Center Beureo of Statistics (2012). Available from: http://cbs.gov.np/?p=2447

14. Center Beureo of Statistics. National Population and Housing Census Report (2011). Report No.

15. Department of Health Service TK. Executive Summary. In: Services DoH, editor. Annual Report. Kathmandu: Government of Nepal (2013).

16. Warwick H, Doig A. Smoke - The Killer in the Kitchen. International Technology Development Group (ITDG) (2004).

17. Israel GD. Determining Sample Size: University of Florida Cooperative Extension Service. Institute of Food and Agriculture Sciences, EDIS (1992).

18. Chowdhury Z, Campanella L, Gray C, Al Masud A, Marter-Kenyon J, Pennise D, et al. Measurement and modeling of indoor air pollution in rural households with multiple stove interventions in Yunnan, China. Atmos Environ (2013) 67:161-9. doi:10.1016/j.atmosenv.2012.10.041
19. Dasgupta S, Huq M, Khaliquzzaman M, Pandey K, Wheeler D. Indoor air quality for poor families: new evidence from Bangladesh. Indoor Air (2006) 16(6):426-44. doi:10.1111/j.1600-0668.2006.00436.x

20. Klepeis NE, Ott WR, Switzer P. A multiple-smoker model for predicting indoor air quality in public lounges. Environ Sci Technol (1996) 30(9):2813-20. doi:10.1021/es960067f

21. Kituyi E, Marufu L, Wandiga SO, Jumba IO, Andreae MO, Helas G. Carbon monoxide and nitric oxide from biofuel fires in Kenya. Energy Convers Manag (2001) 42(13):1517-42. doi:10.1016/S0196-8904(00)00158-8

22. Luby SP, Brooks WA, Zaman K, Hossain S, Ahmed T. Infectious diseases and vaccine sciences: strategic directions. J Health Popul Nutr (2008) 26(3):295-310.

23. Pradhan SR. Pneumonia Perceptions and Management: A Focused Ethnographic Study in Rural Area of Lalitpur (2006). Available from: https://www.duo.uio.no/ handle/10852/30065? show=full

24. Shrestha IL, Shrestha SL. Indoor air pollution from biomass fuels and respiratory health of the exposed population in Nepalese households. Int J Occup Environ Health (2005) 11(2):150-60. doi:10.1179/oeh.2005.11.2.150

25. Pandey M, Neupane R, Gautam A, Shrestha I. Domestic smoke pollution and acute respiratory infections in a rural community of the hill region of Nepal. Environ Int (1989) 15(1):337-40. doi:10.1016/0160-4120(89)90046-9

26. Nepal M, Bhattarai M. Misdiagnosis of COPD in middle-aged asthmatics in Nepal. Int J Pulmon Med (2007) 10(1).

27. Smith KR, Mehta S, Maeusezahl-Feuz M. Indoor Air Pollution from Household use of Solid Fuels. Health and environment linkage initiatives (HELI), WHO (2004). Available from: http://www.who.int/heli/risks/indoorair/indoorairdirectory/en/

28. Singh AL, Jamal S. A study of risk factors associated with indoor air pollution in the low income households in Aligarh city, India. J Environ Res Manag (2012) 3:1-8.

29. Perez-Padilla R, Schilmann A, Riojas-Rodriguez H. Respiratory health effects of indoor air pollution. Int J Tuberc Lung Dis (2010) 14(9):1079-86.

30. Kurmi OP, Semple S, Simkhada P, Smith WCS, Ayres JG. COPD and chronic bronchitis risk of indoor air pollution from solid fuel: a systematic review and meta-analysis. Thorax (2010) 65(3):221-8. doi:10.1136/thx.2009. 124644

31. Bruce NG, Dherani MK, Das JK, Balakrishnan K, Adair-Rohani H, Bhutta ZA, et al. Control of household air pollution for child survival: estimates for intervention impacts. BMC Public Health (2013) 13(Suppl 3):S8. doi:10.1186/14712458-13-S3-S8

32. Zhang JJ, Smith KR. Household air pollution from coal and biomass fuels in China: measurements, health impacts, and interventions. Environ Health Perspect (2007) 115(6):848. doi:10.1289/ehp.9479

33. Baland JM, Bardhan P, Das S, Mookherjee D, Sarkar R. The environmental impact of poverty: evidence from firewood collection in rural Nepal. Econ Dev Cult Change (2010) 59(1):23-61. doi:10.1086/655455

34. Acharya J, Bajgain MS, Subedi MPS. Scaling up biogas in Nepal: what else is needed? Boiling Point (2005) 50:1-4.

35. Von Schirnding Y. Addressing the Impact of Household Energy and Indoor Air Pollution on the Health of Poor: Implications for Policy Action and Intervention Measures. Geneva: World Health Organization (2002).

36. Park K. Park's Textbook of Preventive and Social Medicine. Jabalpur: M/s BANARSIDAS BHANOT (2009).

Conflict of Interest Statement: The authors declare that the research was conducted in the absence of any commercial or financial relationships that could be construed as a potential conflict of interest.

Received: 15 November 2014; accepted: 06 January 2015; published online: 26 January 2015.

Citation: Ranabhat CL, Kim C-B, Kim C-S, Jha N, Deepak KC and Connel FA (2015) Consequence of indoor air pollution in rural area of Nepal: a simplified measurement approach. Front. Public Health 3:5. doi: 10.3389/fpubh.2015.00005

This article was submitted to Environmental Health, a section of the journal Frontiers in Public Health.

Copyright (c) 2015 Ranabhat, Kim, Kim, Jha, Deepak and Connel. This is an openaccess article distributed under the terms of the Creative Commons Attribution License (CC BY). The use, distribution or reproduction in other forums is permitted, provided the original author(s) or licensor are credited and that the original publication in this journal is cited, in accordance with accepted academic practice. No use, distribution or reproduction is permitted which does not comply with these terms. 